\title{
Optimization of Colloidal Chitin and Inoculum Concentration in Chitinase Production by Streptomyces sp. PB2 Using Response Surface Methodology
}

\author{
Eri Pramesti and Indun Dewi Puspita* \\ Department of Fisheries, Faculty of Agriculture, Universitas Gadjah Mada, Jl. Flora A4, Bulaksumur, \\ Yogyakarta, Indonesia
}

\begin{abstract}
Chitinase is an enzyme capable of catalyzing the hydrolysis of chitin. Bacteria is one of the sources for chitinase and the modification process of production are continously developed. Streptomyces sp. is one of Actinomycetes group that shows high activity in hydrolyzing chitin. This study aimed to find the optimal conditions of Streptomyces sp. PB2 for producing chitinase at various colloidal chitin $(0.5 \%, 1 \%, 1.5 \%)$ and inoculum $(0.5 \%, 1 \%, 1.5 \%)$ concentration in the chitin broth medium using Respons Surface Methodology (RSM). The examined parameters included Total Plate Count $(\mathrm{CFU} / \mathrm{ml})$ and chitinase activity $(\mathrm{U} / \mathrm{ml})$. Chitinase activity was statistically analyzed by MiniTab 17 to obtain a mathematical model, then were validated. The mathematical model of chitinase activity was $\mathrm{Y}=-0.000075+0.00056 \mathrm{~K}+0.00067 \mathrm{I}$, with the optimum colloidal chitin concentration (K) of $1.5 \%$ and inoculum concentration (I) of $1.5 \%$. The highest chitinase activity of $0.0019 \mathrm{U} / \mathrm{ml}$ in day-2 fermentation. The validation test showed that the mathematical model had a low accuracy with the SSE value of 0.5306 . This study shows that colloidal chitin and inoculum concentration are important factors to be optimized. However, further model is needed to be developed for a better estimation of process.
\end{abstract}

\section{Introduction}

Chitinase is an enzyme catalyzing the hydrolysis of $\beta-1,4$-glycosidic bond of chitin. It is also well-known enzyme having capability to produce value-added product derived from shrimp shell waste such as chitin and/or chitosan oligomers, $\mathrm{N}$-acetylglucosamine, and glucosamine which can be applied in food, cosmetics, and biomedical industries [1] [2]. Basically, hydrolysis of chitin is carried out through the enzymatic or chemical process. However, enzymatic hydrolysis, in which chitinolytic microorganism plays an important role in this process, is preferable compare to the chemical process as it offers an eco- friendly process, more affordable, and easier to be handled [3].

Approximately $90-99 \%$ chitinolytic bacteria population belongs to the group of Actinomycetes [4]. The Department of Fisheries, Faculty of Agriculture, Universitas Gadjah

*Corresponding author: indun_dp@ugm.ac.id 
Mada have collection of chitinolytic bacteria, including Streptomyces sp. PB2 that previously isolated from shrimp pond-sediment [5]. Further molecular identification revealed that PB-2 was $100 \%$ similar to Streptomyces misionensis based on the $16 \mathrm{~s}$ rRNA analysis[6]. During investigation, Streptomyces sp. PB2 showed a chitinolytic index and chitinase activity of 1.30 and $0.0007 \mathrm{U} / \mathrm{ml}$, respectively, after the fourth day of incubation at $37^{\circ} \mathrm{C}$ [5]. Further study on the optimization of chitinase activity produced in the culture medium of Streptomyces sp. $\mathrm{PB} 2$ revealed that the highest activity was achieved at the incubation condition of $30^{\circ} \mathrm{C}$ and pH $7(0.0017 \mathrm{U} / \mathrm{ml})$. It indicates that environment modification helps to increase chitinase activity in bacterial culture. Another factors that needed to be optimized to increase the chitinase activity in bacterial culture were the level of bacterial inoculum and concentration of colloidal chitin in the medium [7] [8].

Chitinase is an inducible enzyme, which produced by the bacteria when the inducer presents. Chitin stimulates microorganism for releasing chitinase to help the breakdown of the complex polymer of chitin into a simple sugar that will be further uptake as the nutrition by the cell [9]. Beside of the substrate, the number of initial inoculum also affects bacterial enzyme production. Inoculum becomes the critical factor in optimizing chitinase activity by Streptomyces sp. as it relates to lag phase period [10]. High concentration of inoculum may result in non-optimal enzyme formation which caused by competition between bacteria cell dispersed on medium [9]. Hence, substrate concentration and inoculum are two important factors that have to be considered to optimize the bacterial chitinase production.

Factorial experimental design is commonly used to analyze the interaction between two factors in statistical analysis. However, this design requires many experimental units because of the considerable number of treatment combination. Box and Wilson in 1951 conveyed modified method to determine both of experiment effect and optimal point from multifactor experiment known as Response Surface Methodology or RSM [11]. RSM offers an effective and efficient experimental unit in determining the effect and interaction between each factor. This study aimed to determine the optimal combination of colloidal chitin and inoculum concentration for Streptomyces sp. PB2 in producing chitinase using RSM.

\section{Materials and methods}

\subsection{Medium preparation for chitinase production}

Colloidal chitin medium was used for chitinase production. Chitin was extracted from shrimp shell [12] and formed into colloidal chitin [13]. Colloidal chitin medium consisted of $\mathrm{KH}_{2} \mathrm{PO}_{4}$ $(0.03 \%), \mathrm{K}_{2} \mathrm{HPO}_{4}(0.07 \%)$, colloidal chitin $(0.5 ; 1 ; 1.5 \%), \mathrm{MgSO}_{4} .5 \mathrm{H}_{2} \mathrm{O}(0.05 \%), \mathrm{ZnSO}_{4}$ $(0.0001 \%)$, and $\mathrm{MnCl}_{2}(0.0001 \%)$ [14].

\subsection{Inoculum preparation}

Streptomyces sp. PB2 was cultivated in $7 \mathrm{ml}$ nutrient broth (NB) medium on $37^{\circ} \mathrm{C}$ and incubated for 2 days to reach late $\log$ phase (approximately $10 \log \mathrm{CFU} / \mathrm{ml}\left(10^{5}-10^{8}\right)$. Culture was centrifuged at 3,000 rpm for $1 \mathrm{~min}$ and pellet was collected, followed by addition of $1 \mathrm{ml}$ sterile distilled water. The mixture was served as the inoculum stock. The variation of inoculum concentration was prepared by diluting inoculum stock with certain volume of sterile distilled water (Table 1). The concentration on initial cell concentration (inoculum size) in production medium was counted based on aerobic plate count method grown in nutrient agar (NA) at $37^{\circ} \mathrm{C}$ for $18-24$ hours. 
Table 1 Formulation of inoculum concentration

\begin{tabular}{|c|c|c|c|c|}
\hline $\begin{array}{c}\text { Treatment } \\
(\%)\end{array}$ & $\begin{array}{c}\text { Inoculum } \\
\text { Stock }(\boldsymbol{\mu l})\end{array}$ & $\begin{array}{c}\text { Sterile } \\
\text { Distillated } \\
\text { Water }(\boldsymbol{\mu l})\end{array}$ & $\begin{array}{c}\text { Total volume of } \\
\text { inoculum* }(\boldsymbol{\mu l})\end{array}$ & $\begin{array}{c}\text { Bacteria on } \\
\text { production medium } \\
(\mathbf{C F U} / \mathbf{m l})\end{array}$ \\
\hline 0.5 & 50 & 450 & 500 & $2.9 \times 10^{3}$ \\
\hline 1 & 100 & 900 & 1,000 & $1.9 \times 10^{5}$ \\
\hline 1.5 & 150 & 1,350 & 1,500 & $3.8 \times 10^{5}$ \\
\hline
\end{tabular}

*in $100 \mathrm{ml}$ of production medium

\subsection{Optimization of colloidal chitin and inoculum concentration using RSM}

There were 2 treatments used in this experiment, colloidal chitin concentration $(\mathrm{K})$ and inoculum concentration (I). Both factors were set as an independent variable. Three level of inoculum concentrations $(0.5 \% ; 1 \%$, and $1.5 \%$ ) were assigned for each factor (Table 2).

Table 2. Independent variable and treatment code

\begin{tabular}{|c|c|c|c|c|}
\hline \multirow{2}{*}{ Independent Variable } & \multirow{2}{*}{ Symbol } & \multicolumn{3}{|c|}{ Range \& Level } \\
\cline { 3 - 5 } & & $\mathbf{- 1}$ & $\mathbf{0}$ & $\mathbf{+ 1}$ \\
\hline Colloidal chitin concentration (\%) & $\mathrm{X} 1$ & 0.5 & 1 & 1.5 \\
\hline Inoculum concentration (\%) & $\mathrm{X} 2$ & 0.5 & 1 & 1.5 \\
\hline
\end{tabular}

According to the range and level, 8 experimental units were obtained from MiniTab 17 (Table 3). Those experimental units were applied into $100 \mathrm{ml}$ colloidal chitin medium and incubated at $30^{\circ} \mathrm{C}$ using $100 \mathrm{rpm}$ agitation speed for 2 days. Samples were collected every 24 hours for chitinase activity assay.

Table 3. Combination of treatment

\begin{tabular}{|c|c|c|}
\hline Treatment & X1 & X2 \\
\hline A & -1 & -1 \\
\hline B & -1 & +1 \\
\hline C & +1 & -1 \\
\hline D & +1 & +1 \\
\hline E & 0 & 0 \\
\hline F & 0 & 0 \\
\hline G & 0 & 0 \\
\hline H & 0 & 0 \\
\hline
\end{tabular}

\subsection{Chitinase activity assay}

Preparation of sample for chitinase activity assay followed the method of Wang et al. [15]. Briefly, $1 \mathrm{ml}$ culture medium was harvested and centrifuged at $10,000 \mathrm{rpm}$ for $2 \mathrm{~min}$ at $4{ }^{\circ} \mathrm{C}$. The amount of $0.5 \mathrm{ml}$ cell-free supernatant obtained from centrifugation was mixed with 1

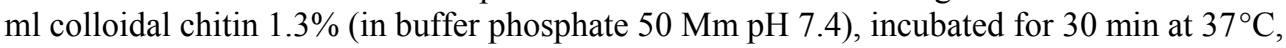
and boiled for $30 \mathrm{~min}$ in boiling water to stop the reaction. After cooled down to reach room temperature $\left(28^{\circ} \mathrm{C}\right)$, mixture was centrifuged at $10,000 \mathrm{rpm}$ for $3 \mathrm{~min}$. The reaction mixture was measured for its $\mathrm{N}$-acetylglucosamine (GlcNAc) content.

GlcNAc content was measured by spectrophotometry [16]. Briefly, $0.25 \mathrm{ml}$ enzymatic reaction mixture was added with $0.05 \mathrm{ml}$ kalium tetraborate $(\mathrm{pH} \mathrm{9.1)}$, incubated in boiled 
water for $3 \mathrm{~min}$, added with $1.25 \mathrm{ml} \mathrm{p}$-dimethylaminobenzaldehyde (DMAB), and incubated at $37^{\circ} \mathrm{C}$ for $30 \mathrm{~min}$. The absorbance of the mixture was measured by UV-Vis spectrophotometer measurement at the wavelength of $540 \mathrm{~nm}$. Negative control and GlcNAc standard were also measured. One unit of chitinase activity was defined as amount of enzyme releasing $1 \mu \mathrm{mol}$ of GlcNAc from chitin hydrolysis reaction each minute under mentioned incubation condition.

\subsection{Data analysis}

Data obtained from this study was analysed statistically. Normality test and homogenity test were performed using R-Studio software to ensure the data met the Anova assumption requirement. For RSM analysis, the statistical test was performed sequentially as followed lack of fit, sum of square and R-square analysis using MiniTab 17 software. The mathematical model was obtained, and the validation test was performed. To measure the discrepancy between the data and an estimation model, sum of squared error (SSE) was calculated.

\section{Results and discussion}

Three concentrations of colloidal chitin $0.5 \% ; 1 \% ; 1.5 \%$ were used. Previous study [10] reported that $1 \%$ chitin concentration helped to produce optimum chitinase activity of Streptomyces sp. ANU6277. Optimum chitinase activity by S. aureofaciens CMUAc130 was also achieved using 1\% colloidal chitin [17]. Another studies reported that the addition of $0.25 \%$ to $1.5 \%$ colloidal chitin in medium helped to improve bacterial chitinase production $[18,19]$. Thus, the level of colloidal chitin of $0.5 \%, 1 \%$, and $1.5 \%$ were chosen as the treatments. Meanwhile, for the inoculum concentration of $10^{3}-10^{6} \mathrm{CFU} / \mathrm{ml}$ were used for the production of chitinase by Streptomyces sp. MBRL10 [20]. Three levels from 2 treatment factors were then combined for further optimization using response surface methodology.

Table 4. Chitinase activity $(\mathrm{U} / \mathrm{ml})$ of Streptomyces sp. PB2 cultured at $30^{\circ} \mathrm{C}, 100 \mathrm{rpm}, 2$ days

\begin{tabular}{|c|c|c|c|}
\hline $\begin{array}{c}\text { Treatment } \\
\text { Combination } \\
\text { Code }\end{array}$ & $\begin{array}{c}\text { Colloidal Chitin } \\
\text { Concentration (\%) }\end{array}$ & $\begin{array}{c}\text { Inoculum } \\
\text { Concentration } \\
(\mathbf{\%})\end{array}$ & $\begin{array}{c}\text { Chitinase Activity } \\
\text { (U/ml) }\end{array}$ \\
\hline A & 0.5 & 0.5 & 0.0001 \\
\hline B & 0.5 & 1.5 & 0.0004 \\
\hline C & 1.5 & 0.5 & 0.0003 \\
\hline D & 1.5 & 1.5 & 0.0013 \\
\hline E & 1 & 1 & 0.0003 \\
\hline F & 1 & 1 & 0.0005 \\
\hline G & 1 & 1 & 0.0004 \\
\hline H & 1 & 1 & 0.0006 \\
\hline
\end{tabular}

The chitinase activity produced after 2 days incubation shows that treatment $\mathrm{D}$, a combination of $1.5 \%$ colloidal chitin and $1.5 \%$ inoculum concentration, resulted in the highest chitinase activity (Table 4). The analysis of Anova assumption (normality and homogenity test) and goodness of fit (lack of fit test, sum of square and R-square test) were employed using MiniTab 17 to obtain the mathematical model. The shapiro normality test 
showed the p-value of 0.09 , meanwhile the homogenity test resulted in p-value of 1 . The pvalue higher than 0.05 indicates that normality and homogenity assumption of the data was achieved and the analysis of statistical model was proceeded.

Table 5. Anova linear model of chitinase activity (combination of colloidal chitin/ K) and inoculum concentration/ I)

\begin{tabular}{|c|c|c|c|c|c|}
\hline $\begin{array}{c}\text { Source of } \\
\text { Variant }\end{array}$ & Df & SS & MS & F-Value & P-Value $^{*}$ \\
\hline Linear & 2 & 0.000001 & 0.000000 & 10.52 & $\mathbf{0 . 0 1 6}$ \\
\hline K & 1 & 0.000000 & 0.000000 & 8.83 & 0.031 \\
\hline I & 1 & 0.000000 & 0.000000 & 12.21 & 0.017 \\
\hline Eror & 5 & 0.000000 & 0.000000 & & \\
\hline Lack of Fit & 2 & 0.000000 & 0.000000 & 3.11 & $\mathbf{0 . 1 8 6}$ \\
\hline Pure Eror & 3 & 0.000001 & 0.000000 & & \\
\hline
\end{tabular}

\footnotetext{
*Significance level 95\%

H0 : Model is not fit $(\mathrm{P}-$-value $>0.05)$

H1 : Model is fit $(\mathrm{P}$-value $<0.05)$
}

Analysis of the goodness-of-fit showed that the p-value obtained from the linear model was 0.018 (Table 5). P-value of less than 0.05 showed that linear model fitted the mathematical model for the chitinase activity produced by Streptomyces sp. PB2. Furthermore, lack of fit analysis was done to measure the fitness of the model to the first order. A good mathematical model is a model without lack of fit [20]. Hypothesis used to conclude this analysis was:

$\mathrm{H}_{0}$ : $\quad$ No lack of fit on the model (P value $\left.>0.05\right)$

$\mathrm{H}_{1}$ : There was lack of fit on the model $(\mathrm{P}-$ value $<0.05)$

P-value obtained (0.354) was higher than 0.05 (Table 5). Therefore, $\mathrm{H}_{0}$ was accepted, meaning that no lack of fit in the model. Based on the Anova regression calculation, the Rsquare value was 0.80 nearly to 1 . The $\mathrm{R}$-square value of nearly to 1 indicates a good model as it fits the data and explains all the variability of data response [20]. R-square of 0.80 showed that chitinase activity was affected by colloidal chitin and inoculum with 0.80 probability.

According to statistical analysis, a linear model was obtained as a mathematical model of RSM for chitinase activity towards colloidal chitin and inoculum concentration as follows:

$$
Y=-0.00075+0.00056 K+0.00067 I
$$

$\mathrm{Y}$ was chitinase activity; $\mathrm{K}$ was colloidal chitin concentration; whereas I was inoculum concentration. From this model, a contour plot of chitinase activity resulted from the combination of various concentrations of colloidal chitin and inoculum was obtained (Figure $1)$. 


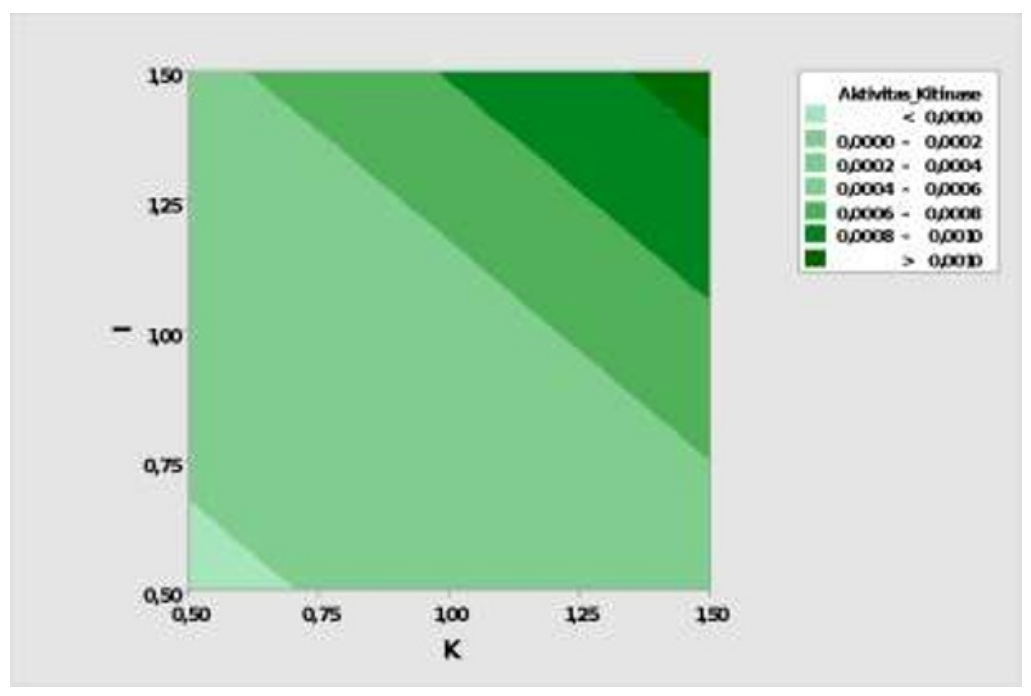

Fig. 1. Contour plot of various concentrations of colloidal chitin and inoculum against chitinase activity

Figure 1 explained that the higher the colloidal chitin and inoculum concentration added to the production medium, the higher the chitinase activity obtained. Our finding revealed that $1.5 \%$ colloidal chitin concentration and $1.5 \%$ inoculum resulted in the highest chitinase activity $(0.0013 \mathrm{U} / \mathrm{ml})$. The same ratio of colloidal chitin concentration and inoculum concentration resulted to the highest chitinase activity in this study.

A lower chitinase activity was obtained from a combination of colloidal chitin and inoculum in a lower concentration than $1.5 \%$. The combination of $0.5 \%$ colloidal chitin and $0.5 \%$ inoculum resulted to the chitinase activity of $0.0001 \mathrm{U} / \mathrm{ml}$, meanwhile $0.5 \%$ colloidal chitin and $1.5 \%$ inoculum produced chitinase activity of $0.0004 \mathrm{U} / \mathrm{ml}$. Low concentration of colloidal chitin may caused an inadequate nutrition to support cell growth as colloidal chitin served as carbon and energy source for bacteria [21]. Low nutrient availability in the medium may result to the competition between bacteria. Furthermore, the combination of higher colloidal chitin (1.5\%) and low concentration of inoculum $(0.5 \%)$ was also resulted to the low chitinase activity. Higher concentration of substrate compared to inoculum concentration may lead to the accumulation of organic acid that decrease the medium $\mathrm{pH}$ and further inhibit cell growth and interfere enzymatic reactions [22].

Validation test with 2 replications was done to observe the goodness-of-fit between mathematical model and observation data. Table 6 shows the comparison of chitinase activity obtained from observation with the value obtained from the calculation using mathematical model. 
Table 6. Mathematical model validation of chitinase activity from the combination of colloidal chitin and inoculum

\begin{tabular}{|c|c|c|c|c|}
\hline $\begin{array}{c}\text { Colloidal chitin } \\
(\%)\end{array}$ & Inoculum $(\%)$ & $\begin{array}{c}\text { Calculated } \\
(\mathrm{U} / \mathrm{ml})\end{array}$ & $\begin{array}{c}\text { Observation } \\
(\mathrm{U} / \mathrm{ml})\end{array}$ & $\mathrm{SE}$ \\
\hline 1.5 & 1.5 & 0.0010 & 0.0019 & 0.2244 \\
\hline 1.5 & 1.5 & 0.0010 & 0.0017 & 0.1696 \\
\hline 2 & 2 & 0.0017 & 0.0024 & 0.0851 \\
\hline 2 & 2 & 0.0017 & 0.0022 & 0.0517 \\
\hline \multicolumn{5}{|c|}{ SSE } \\
\hline
\end{tabular}

Table 6 shows that the observed value of chitinase activity was higher than the calculated chitinase activity obtained from the model. The high value of SSE indicated that the discrepancy between the data obtained from experiment was far from the estimated value using the model obtained from the RSM analysis. This result indicated that the development of other model was required.

The optimum chitinase activity in this study was reached at day-2 with the value of $0.0019 \mathrm{U} / \mathrm{ml}$. The highest chitinase activity of $0.0017 \mathrm{U} / \mathrm{ml}$ was obtained from Streptomyces sp. PB2 at day- 6 of incubation before the optimization process. using the combination of 2 $\%$ colloidal chitin and $1 \%$ inoculum [23]. This study shows that optimization of colloidal chitin and inoculum concentration in the medium accelerated the period of chitinase production by Streptomyces sp. PB2. However, chitinase activity produced by Streptomyces sp. PB2 from this study was lower compared to other report on Streptomyces sp. chitinase. Chitinase activities of Streptomyces sp. NK1057, Streptomyces sp. NK528, and Streptomyces sp. NK951 were reported upon the optimization of colloidal chitin and inoculum concentration along with other components of medium using RSM. Optimum chitinase activities from the highest to the lowest were $325 \mathrm{mU} / \mathrm{ml}$ by Streptomyces sp. NK1057, 194 $\mathrm{mU} / \mathrm{ml}$ by Streptomyces sp. NK528, and $132 \mathrm{mU} / \mathrm{ml}$ by Streptomyces. sp. NK951 with the ratio of colloidal chitin concentration of $20.96,15$, and $15 \mathrm{~g} / \mathrm{l}$, respectively, with the same inoculum desnity of 0.15 [24]. Further optimization of growth condition for Streptomyces sp. PB2 is needed to achieve higher chitinase activity of the culture.

\section{Conclusion}

Chitinase activity of Streptomyces sp. PB2 was optimized by the combination of colloidal chitin and inoculum concentration in the medium. Statistical analysis using RSM obtained the mathematical model for chitinase activity of $\mathrm{Y}=-0.00075+0.00056 \mathrm{~K}+0.00067 \mathrm{I}$. With the optimum colloidal chitin concentration $(\mathrm{K})$ of $1.5 \%$ and inoculum concentration (I) of $1.5 \%$. This study shows that colloidal chitin and inoculum concentration are the important factors to be optimized in order to reach an optimal production of bacterial chitinase.

\section{Acknowledgement}

This study was supported by the RTA program 2019. 


\section{References}

1. N. Herdyastuti, T.J. Raharjo, Mudasir, S. Matjeh, Indonesian Journal of Chemistry 9, 37-47 (2009)

2. A. Wirawan, N. Herdyastuti, Journal of Chemistry 2, (2013)

3. V. Gohel, A. Singh, M. Vimal, P. Ashwini, H.S. Chhatpar. African Journal of Biotechnology 5, 54-72 (2008)

4. G. Mukherjee, S.K. Sen. Current Microbiology 53, 265-259 (2004)

5. A. Kholifah. Skripsi Universitas Gadjah Mada (2015)

6. A.U. Triwijayani. Skripsi Universitas Gadjah Mada (2016)

7. J. Monreal, E.T. Reese, Journal of Microbiology 15, 689-696 (1968)

8. J.K. Chen, C.R. Shen, C.L. Liu, Marine Drugs 8, 2493-2516 (2010)

9. J.C. Augustin, A. Brouillaud-Delattre, L. Rosso, V. Carlier, Journal Applied and Environmental Microbiology 66, 1706-1710 (2000)

10. K. Narayana. M. Vijayalakshmi. Journal Microbiology 40, 725-733 (2009)

11. A.R.P. Putra. Skripsi Univiersitas Indonesia (2012)

12. A. Hargono and I. Sumantri. Reaktor 12, 53-57 (2008)

13. L.D. Arnold. Solomon. Manual of Industrial Microbiology and Biotech (ASM, Washington, 1986)

14. S. Hsu. C. Lockwood. Applied Microbiology 29, 422-426 (1974)

15. S.L. Wang. B.S. Lin. T.W. Liang. C.L. Wan. P.C. Wu. and J.R. Liu. Journal of Microbiology and Biotechnology 20, 1001-1005 (2010)

16. J.L. Reissig. J.L. Strominger. L.F. Leloir. The Journal of Biological Chemistry 217, 959966 (1955)

17. T. Taechowisan. J.F. Peberdy, and S. Lumyong. Annals of Microbiology 53, 4, 447-462 (2003)

18. Gupta. R. Saxena. R.K. Chaturvedi. P. Viridi. Journal Applied Bacteriology 78, 378-383 (1995)

19. A. Shivalee. K. Lingappa. Divatar. Mahesh. Journal of Genetic Engineering and Biotechnology 16, 412-426 (2018)

20. C.P. Bakti. Skripsi Universitas Indonesia (2012)

21. K.A. Tamreihao. S. Nimaichand.. S.B. Chanu.. K.A. Devi.. R. Lynda.. N.Jeeniita.. S. Debananda. Ningthoujam. Journal of King Sa ud University Science 30, 143-152 (2018)

22. A. Widodo. Skripsi Universitas Gadjah Mada (2018)

23. F. Indah. Skripsi Universitas Gadjah Mada (2008)

24. N. Nawani and B.P Kapadnis. Process Biochemistry 40, 2, 651-660 (2005). 